\title{
Fishers' perception on co-operative services and willingness-to-pay (WTP) for improved fish marketing services at Njarakkal, Ernakulam District, Kerala
}

\author{
P. JEYANTHI, V. CHANDRASEKAR AND NIKITA GOPAL \\ ICAR-Central Institute of Fisheries Technology, Matsyapuri P.O., Willingdon Island, Kochi - 682029 \\ Kerala, India \\ e-mail:tvjeyanthi@gmail.com
}

\begin{abstract}
Fishermen co-operatives play a vital role in providing services which are uniform in nature. But, the perception of fishermen regarding co-operative services is generally subjective. This study assessed the fishermens' perception at Njarakkal, Ernakulam District, Kerala, regarding the services of co-operatives. It was found from the results that $90 \%$ of respondents strongly agreed that they were earning profit by selling fish through co-operatives. More than $80 \%$ accepted that co-operatives were the best credit source, binding the fishermen and improving standard of living. About $50 \%$ felt that co-operatives had no role in fisheries management. Besides provision of credit, fish auctioning is an important service rendered by fishermen co-operatives. It has been felt that there is lack of proper infrastructure facilities, especially cold storage facility in the domestic fish marketing system. The willingness-to-pay for improved marketing services at Njarakkal was also evaluated during this study. The willingness-to-pay for setting up cold storage facility was assessed using logistic model. Results revealed that $65 \%$ of respon dents are willing-to-pay for the cold storage facility. The results of logistic regression analysis showed that member's satisfaction regarding co-operative activities is the most significant factor which decides their willingness-to-pay for the improved marketing services.
\end{abstract}

Keywords: Co-operatives, Fishermen, Logistic regression model, Marketing, Perception, Willingness-to-pay

Fish is a highly perishable commodity that needs much attention during transportation and handling till it reaches the consumer (Bensam, 1999). In India, around $85 \%$ of fish is traded in domestic markets and around $70 \%$ is traded as fresh fish. Hence, there is lot of chance for spoilage during handling and transportation. Fish spoilage is mainly attributed to the absence of proper cold storage facilities to preserve the off-season and off-time fish catch. Fish spoilage accounted for $10-15 \%$ of the fish quantity traded (Chea and Mckenny, 2003). There is difficulty in transporting fish to the non-coastal and interior areas due to lack of cold storage facilities. In India, there are initiatives by National Fisheries Development Board (NFDB) towards improving the cold chain of hygienic retail outlets at varying levels which includes installation of cold storage facility also.

In Kerala, the first initiative to form fishermen co-operatives was taken during 1917, with three-tier structure coming into force i.e., primary co-operatives at village level, secondary co-operatives at district level and apex co-operatives at state level with definite roles and responsibilities. Later, the primary activities of credit were diversified into various business and welfare aspects. Fish selling through fishermen co-operatives is one such activity which earns considerable amount of profit to both fishermen and co-operative societies.
Gibson (1978) highlighted the role of fishing co-operatives in providing platform for processing and export facilities to fisher members. He found that members of co-operatives were enjoying more benefits such as loan facilities for purchase of craft and gear accessories for fishing. The co-operatives frequently face financial, mechanical, social and cultural issues which affect effective functioning. Some of the important drawbacks are lack of adequate cold storage facilities, processing equipment and ice-making machines. The study has been carried out to determine the fishers' willingness-to-pay for improved marketing services at Narakkal in Ernakulam District of Kerala.

Matsyafed (Kerala State Co-operative Federation for Fisheries Development Ltd.) is instrumental in facilitating fish auctioning through Fishermen Development Welfare Co-Operative Societies. There were 232 fishermen co-operative societies involved in fish auctioning with 43,330 fishermen, which sold 52,049 t of fish and earned about ₹142.15 crores during 2010 (Matsyafed, 2015). In Ernakulam District, there were 55 functional fishermen co-operatives which are mainly under the supervision and control of Matsyafed. The aim of Matsyafed is to liberate fishermen from the middlemen exploitation through providing cheaper credit and common platform towards decision making. 
For the present study, the Njarakkal Nayarambalam Fishermen Development Welfare Co-operative Society in Narakkal Panchayat, Vypeen Island, Ernakulum, Kerala (Fig. 1) was purposively selected. In Ernakulam District, around $50 \%$ of fishers were members of fisheries co-operatives (CMFRI, 2012). Among the respondents, 75 members were randomly contacted for the study to assess the perceived willingness-to-pay for the improved marketing services.

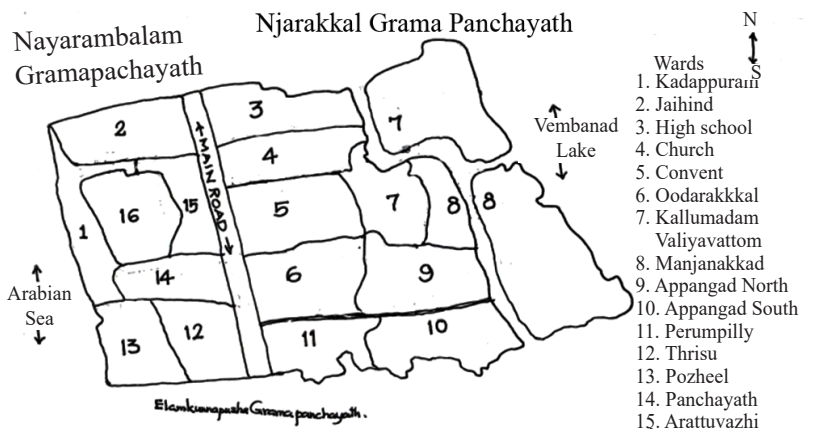

Fig. 1. Location map of Njarakkal Panchayat, Ernakulam District

During 2011-12, eighteen groups comprising of 671 member fishers availed fish auctioning services through Njarakkal co-operatives (Table 1). The quantity of sale was $32,909 \mathrm{t}$ with auction value of ₹873 lakhs and the society earned a commission of ₹13.09 lakhs. Usually, the society charges $6 \%$ as commission for fish auctioning services which comprises of $1 \%$ commission to Matsyafed, $1.5 \%$ to fish auctioneer, $1.5 \%$ to the owner of the fishing boat and $1 \%$ to the society. The $1 \%$ commission to society will be paid in return as a bonus during festive season.

Table 1. Performance of co-operatives in fish auctioning

\begin{tabular}{lclll}
\multicolumn{5}{c}{$(2003-2011)$} \\
Year & Group & Members & $\begin{array}{l}\text { Auction value } \\
\text { (₹ lakhs) }\end{array}$ & $\begin{array}{l}\text { Quantity } \\
\text { (t) }\end{array}$ \\
\hline 2003 & 16 & 505 & 350 & 1752 \\
2004 & 16 & 505 & 398 & 1992 \\
2005 & 16 & 505 & 594 & 2970 \\
2006 & 18 & 513 & 529 & 2645 \\
2007 & 16 & 505 & 620 & 3100 \\
2008 & 17 & 574 & 702 & 3514 \\
2009 & 17 & 574 & 1133 & 5669 \\
2010 & 18 & 671 & 1380 & 6901 \\
2011 & 18 & 671 & 873 & 4366 \\
Total & 134 & 4581 & 6579 & 32909 \\
\hline
\end{tabular}

The fishermen perception on co-operative services was estimated using Likert scale with a five point scale (Zarafshani et al., 2010). The qualitative scale of agree, strongly agree, disagree, strongly disagree and neutral was used to categorise the perception and characteristics of co-operatives. The Logistic model was fitted to assess the fishermen co-operative members' willingness-to-pay (WTP) for improved marketing services.

Improved marketing services include establishment of cold storage facilities by the co-operatives for facilitating fish marketing activities of respondents towards reducing loss due to post-harvest handling. The model was run using the variables viz., age, education, membership, satisfaction and fish marketing activities of respondents. The bivariate analysis explained the factors influencing the willingness-topay among the variables selected. The perceived willingness to pay of the member fishers towards the improved marketing services was analysed using binary logistic regression analysis (Uva and Cheng, 2005; Tinashe et al., 2013). The mathematical derivation of model is as follows:

$$
\mathrm{Zi}=\log \left[\frac{\mathrm{Pi}}{1-\mathrm{Pi}}\right]=\alpha_{0}+\alpha_{1} \mathrm{X}_{1}+\alpha_{2} \mathrm{X}_{2}+\alpha_{3} \mathrm{X}_{3}+\alpha_{4} \mathrm{X}_{4}+\alpha_{5} \mathrm{X}_{5}+\varepsilon
$$

where, $X_{1}=$ Age of the respondent (indicates age of the fishermen who are members of the fishermen co-operatives)

$\mathrm{X}_{2}=$ Education level of the respondent (indicates education level of the fishermen)

$\mathrm{X}_{3}=$ Membership status (indicates duration as members in the fishermen co-operatives and mentioned in years)

$\mathrm{X}_{4}=$ Members' satisfaction (indicates the opinion of the fishermen on co-operative services,' 1 ' jindicates satisfaction and ' 0 ' indicates not satisfied)

$\mathrm{X}_{5}=$ Fish marketing through co-operatives (indicates the fishermen members who are selling fish through co-operatives, ' 1 ' indicates yes and ' 0 ' indicates 'No')

$\varepsilon=$ error term (Zhao et al., 2010)

Narakkal-Nayarambalam Fishermen Development Welfare Co-Operative Society at Narakkal, Ernakulam District came into existence in 1988 and the membership strength was 3123 fishers during 2011. The general activities of co-operatives are credit, fish auctioning, provisional stores, technical assistance, insurance, input sales and welfare activities. Unal et al. (2009) identified that the responsibilities of fishermen co-operatives in Turkey were organisation of credits, production, marketing and construction of cold storage.

From the results of the study, it was found that $94 \%$ of respondents agreed or strongly agreed that they were earning profit by fish selling through co-operatives similar to earlier report (Zarafshani et al., 2010). More than 80\% accepted that co-operatives were the best credit source, ensured unity among fishermen and improved standard of living (Table 2). Two aspects viz., stakeholders' perception and satisfaction on co-operative services determined 
Table 2. Fishermen perception on Fisheries co-operative services $(\%)$

\begin{tabular}{|c|c|c|c|c|c|}
\hline Particulars & $\mathrm{SA}^{*}$ & $\mathrm{~A}^{*}$ & $\mathrm{~N}^{*}$ & $\mathrm{D}^{*}$ & $\mathrm{SD}^{*}$ \\
\hline $\begin{array}{l}\text { Potential and attractive } \\
\text { credit source }\end{array}$ & 2 & 86 & 4 & 8 & 0 \\
\hline Ensure fishermen unity & 4 & 78 & 6 & 12 & 0 \\
\hline $\begin{array}{l}\text { Provide training on fishing } \\
\text { activities }\end{array}$ & 0 & 18 & 24 & 54 & 4 \\
\hline $\begin{array}{l}\text { Satisfying the needs of } \\
\text { fishermen }\end{array}$ & 2 & 52 & 20 & 26 & 0 \\
\hline Fish selling is profitable & 4 & 90 & 4 & 2 & 0 \\
\hline $\begin{array}{l}\text { Improves standard of living } \\
\text { of fishermen }\end{array}$ & 2 & 86 & 2 & 6 & 0 \\
\hline
\end{tabular}

the co-operatives' performance as reported previously (Unal et al., 2009).

More than $50 \%$ felt that co-operatives had no role in fisheries management. The major determinants of the fishermen perception were the role of co-operatives in input supply (94\%), client friendliness (92\%) and hassle free procedures for approval and repayment of loans (89\%) (Table 3).

The co-operatives were preferred least due to the lack of timely loans (33\%) and non-provision of technical assistance (29\%). Unal and Yercan (2006) also stated that co-operatives were not professionally managed and generally performed below the standard level of efficacy. On the other hand, Baticados et al. (1998) reported that co-operatives were helpful in co-managing fisheries resources and members were also willing to assume responsibilities.

The average age of the member fishers was 36 years and majority of them completed middle school $(66 \%)$. It was understood from the previous studies that there were significant contribution of education and income towards perceived willingness-to-pay for conservation activities (Scott and Willits, 1994; Chen et al., 2011). Family size of the respondents varied between 2 to 6 and the average family

Table 3. Determinants of fishers' perception on co-operative services $(\%)$

\begin{tabular}{llllll}
\hline Particulars & $\mathrm{SA}^{*}$ & $\mathrm{~A}^{*}$ & $\mathrm{~N}^{*}$ & $\mathrm{D}^{*}$ & $\mathrm{SD}^{*}$ \\
\hline Client-friendliness & 6.25 & 85.42 & 4.17 & 4.17 & 0.00 \\
Timely loan availability & 4.17 & 29.17 & 16.67 & 50.00 & 0.00 \\
Profitability & 4.17 & 83.33 & 4.17 & 6.25 & 2.08 \\
Technical assistance & 0.00 & 22.92 & 25.00 & 52.08 & 0.00 \\
Input supply & 2.08 & 43.75 & 31.25 & 16.67 & 6.25 \\
Hassle-free procedures & 2.08 & 87.50 & 4.17 & 2.08 & 4.17 \\
Repayment flexibility & 6.25 & 43.75 & 12.50 & 33.33 & 4.17
\end{tabular}

"SA - Strongly agree, A - Agree, N - Neither agree nor disagree, SD - Strongly disagree, D - Disagree income of the respondents was ₹12435/-. Their mainstay was fisheries with no alternative livelihood opportunities for fishers. The respondents were selling fish through fisheries co-operatives on an average for 12 years. It was found that the respondents completed at least primary level of education which formed the predominant group (67.82\%).

The descriptive statistics of the variables selected for the logistic model showed that $64.19 \%$ of members fell in the age group of 30-50 years with majority of them having above primary level of education (67.82\%). More than 75 and $65 \%$ of fisher members were satisfied with the services provided by co-operatives and WTP for improved marketing services as reported earlier (Uva and Cheng, 2005) (Table 4).

It was evident that among the variables selected (Table 4), fisher members who are willing-to-pay for improved marketing services were those below the age of 30 years with above primary education and selling fish through co-operations for more than 5 years. They were in fact associated with the co-operatives for more than 10 years (Table 5).

Among the variables studied, member's satisfaction regarding co-operative activities are the significant factor with positive relationship which decides their willingnessto-pay for the improved marketing services (Table 6). The variables such as age, education and membership showed no significant relation with member's satisfaction regarding co-operative activities. From this, it was revealed that the satisfaction of members on co-operative activities is the prime factor determining the WTP for the improved

Table 5. Bivariate analysis of members' characteristics and factors influencing the willingness-to-pay (\%)

\begin{tabular}{lcc}
\hline Variables & $\begin{array}{l}\text { WTP } \\
(\mathrm{N}=69)\end{array}$ & $\begin{array}{l}\text { Non-WTP } \\
(\mathrm{N}=36)\end{array}$ \\
\hline Age & & \\
\hline Below 30 & 77.82 & 22.18 \\
Above 30 & 68.25 & 31.75 \\
$\begin{array}{lc}\text { Education } \\
\text { Below primary level }\end{array}$ & 66.81 \\
Above primary level & 33.19 & 20.74 \\
\hline Fish marketing through co-operatives & \\
\hline Less than 5 yrs & 45.89 & 54.11 \\
More than 5 yrs & 68.45 & 31.55 \\
\hline Co-operative member - relationship & \\
\hline Co-operative member $<10$ yrs & 55.23 & 44.77 \\
Co-operative member $>10$ yrs & 75.69 & 24.31 \\
\hline Satisfaction with co-operative services & \\
\hline Satisfied & 66.00 & 34.00 \\
Not satisfied & 42.65 & 57.35 \\
\hline
\end{tabular}


Table 4. Descriptive statistics of variables used in Logistic model

\begin{tabular}{|c|c|c|c|c|c|}
\hline Variables & Code & Min. & Max. & Mean & $\begin{array}{l}\text { Distribution }(\%) \\
(\mathrm{n}=105)\end{array}$ \\
\hline \multicolumn{6}{|l|}{ Age of member fisher } \\
\hline Below $30=1$; otherwise $=0$ & Age 1 & 0 & 1 & 0.17 & 6.96 \\
\hline $30-50$ yrs $=1 ;$ otherwise $=0$ & Age 2 & 0 & 1 & 0.59 & 64.19 \\
\hline Above $50 \mathrm{yrs}=1$; otherwise $=0$ & Age 3 & 0 & 1 & 0.24 & 28.85 \\
\hline \multicolumn{6}{|l|}{ Education level of member-fisher } \\
\hline Below primary level $=1$; otherwise $=0$ & Edu 1 & 0 & 1 & 0.38 & 32.18 \\
\hline Above primary level $=1 ;$ Otherwise $=0$ & Edu 2 & 0 & 1 & 0.62 & 67.82 \\
\hline \multicolumn{6}{|l|}{ Fish marketing through co-operatives } \\
\hline Less than 5 years $=1$; otherwise $=0$ & Fishmar 1 & 0 & 1 & 0.28 & 24.14 \\
\hline More than 5 years $=1$; otherwise $=0$ & Fishmar 2 & 0 & 1 & 0.72 & 75.86 \\
\hline \multicolumn{6}{|l|}{ Co-operative-member relationship } \\
\hline Co-operative member $<10 \mathrm{yrs}=1$; otherwise $=0$ & CM-RELN 1 & 0 & 1 & 0.41 & 39.81 \\
\hline Co-operative member $>10$ yrs $=1$; otherwise $=0$ & CM-RELN 2 & 0 & 1 & 0.59 & 60.19 \\
\hline \multicolumn{6}{|l|}{ Satisfaction with co-operative services } \\
\hline Satisfied $=1$; otherwise $=0$ & Satifn 1 & 0 & 1 & 0.74 & 76.27 \\
\hline Not satisfied $=1$ : otherwise $=0$ & Satifn 2 & 0 & 1 & 0.26 & 23.73 \\
\hline \multicolumn{6}{|l|}{ Willingness to pay for improved marketing services } \\
\hline Yes $=1 ;$ otherwise $=0$ & Wtp 1 & 0 & 1 & 0.63 & 65.39 \\
\hline No $=1 ;$ otherwise $=0$ & Wtp 2 & 0 & 1 & 0.37 & 34.61 \\
\hline
\end{tabular}

Table 6. Logistic results of willingness-to-pay (WTP) for improved fish marketing services

\begin{tabular}{ll}
\hline Parameter & Estimate \\
\hline Intercept & 11.965 \\
Age & 0.767 \\
Education & -0.653 \\
Membership & -0.571 \\
Member's satisfaction & $11.082^{* *}$ \\
Fish marketing through co-operatives & $-23.720^{* *}$ \\
Likelihood ratio & $21.802^{* *}$ \\
\hline
\end{tabular}

${ }^{* *}$ Significant at $1 \%$ level

marketing services. Bhuyan (2007) suggested that without active members 'participation and of members satisfaction, co-operatives cannot survive in the long run.

Among the respondents studied, $66 \%$ were willing-to-pay for the installation of improved marketing services. The amount, which they were willing-to-pay for improved marketing services, varied between ₹ 10 to 50/-. The mode and frequency of payment also differed between respondents (Table 7).

Majority of the fisher members preferred to make the payment in cash $(70.67 \%)$ separately rather than deduction along with commission charges for fish auctioning. The preferred frequency of payment by the fisher members was 68,24 and $8 \%$ for daily, weekly and monthly instalments respectively.

The services provided by the fishermen co-operatives have diversified over the period of time from credit to
Table 7. Fishers' options on WTP for improved marketing services

\begin{tabular}{lll}
\hline Particulars & Frequency & Percentage \\
\hline Category & & \\
$\quad$ Willing to pay ₹10 & 47 & 45.16 \\
Willing to pay ₹11-20 & 22 & 21.12 \\
Willing to pay ₹21-30 & 17 & 16.43 \\
Willing to pay ₹31-40 & 13 & 12.15 \\
$\quad$ Willing to pay ₹41-50 & 6 & 5.14 \\
Mode of payment & & \\
$\quad$ Willing to pay as cash & 74 & 70.67 \\
$\quad$ Willing to pay along with & 31 & 29.33 \\
$\quad$ commission charges & & \\
Payment frequency & & \\
$\quad$ Daily & 72 & 68.00 \\
$\quad$ Weekly & 25 & 24.00 \\
Monthly & 8 & 8.00 \\
\hline
\end{tabular}

business and welfare activities. From the results of the study it is evident that the fishermen co-operatives played a major role in improving the livelihood of fishermen through bonding fishermen, input supply and facilitating fish auctioning activity. The members with more years of association and those selling fish through auctioning were willing-to-pay more for the improved marketing services. The member's participation in the co-operatives was a significant factor in determining the willingness-to-pay of fishermen towards improved fish marketing services.

\section{Acknowledgements}

The authors gratefully acknowledge Dr. C. N. Ravishankar, Director, ICAR-CIFT, Kochi who gave 
permission to present the paper. Thanks are due to Shri. K. D. Jos, Senior Technical Officer, ICAR-CIFT, Kochi for the tireless technical support during the period of study.

\section{References}

Baticados, D. B., Agbayani, R. F. and Gentoral, F. E. 1998. Fishing Co-operatives in Capiz, Central Philippines: their importance in managing fishery resources. Fish. Res., 34: 137-149.

Bensam, P. 1999. Development of marine fisheries science in India. Daya Publishing House, New Delhi, India, 339 pp.

Bhuyan, S. 2007. The "people" factor in cooperatives: An analysis of members' attitudes behavior. Can. J. Agr. Econ., 55: $275-298$.

Chea, Y. and Mckenny, B. 2003. Domestic fish trade: A case study of fish marketing from the Great Lake to Phnom Penh. Working paper 29, Cambodia Development Resource Institute, 24 pp.

Chen, X. D., Peterson, M. N., Hull, V., Lu, C. T., Lee, G. D., Hong, D. Y. and Liu, J. G. 2011. Effects of attitudinal and sociodemographic factors on pro-environmental behaviour in urban China, Environ. Conserv., 38(1): 45-52.

CMFRI 2012. Marine fisheries census 2010 - Part I India. Central Marine Fisheries Resrach Institute, Kochi.

Gibson, J. 1978. The successes and failures of the fishing cooperatives of Belize. In: Proceedings of the Gulf and Caribbean Fisheries Institute, 30, Gulf and Caribbean Fisheries Institute, p. 130-140.
Scott, D. and Willits, F. K. 1994. Environmental attitudes and behavior: A Pennsylvania survey. Environ. Behav., 26(2): 239-260.

Tinashe, M. V., Edward, M., Dadirayi, M., Never, M., Godfrey, C., Joseph, M. and Joseph, C. 2013. An analysis of the factors influencing the smallholder communal cotton farmers' decision to adopt contract farming. A case of Zaka District. Bull. Environ. Pharmacol. Life Sci., 12(6): 131-134.

Unal, V. and Yercan, M. 2006. Fishery co-operatives in Turkey and their importance for fishermen. J. Fish. Aquat. Sci., 23: 221-227.

Unal, V., Guclusoy, H. and Franquesa, R. 2009. A comparative study of success and failure of fishery co-operative in the Aegea, Turkey. J. Appl. Ichthyol., 25: 394 - 400.

Uva, W. L. and Cheng, M. 2005. Consumer willingness-to-pay and marketing opportunity for quality guaranteed tree-ripened peaches in New York State. J. Food Distrib. Res., 36: 177-184.

Matsyafed 2015. Kerala State Co-operative Federation for Fisheries Development Ltd. www.fisheries.kerala.gov.in, (Accessed 22 April 2015).

Zarafshani, K., Rostamitabar, F., Hosseininia, G. H., Akbari, M. and Azadi, H. 2010. Are agricultural production co-operatives successful? A case study in Western Iran. American-Eurasian J. Agric. Environ. Sci., 8(4): 482 - 486.

Zhao, R., Qiao, J. and Chen, Y. 2010. Influencing factors of consumer willingness-to-buy traceable foods: An analysis of survey data from two Chinese cities. Agric. Agric. Sci. Procedia, 1: 334-343.

Date of Receipt $\quad$ : $\quad 08.09 .2016$

Date of Acceptance ： $\quad 02.04 .2017$ 